\title{
Potential of Opuntia seed oil for livelihood improvement in semi-arid Madagascar
}

\author{
Hendrik Hänkel, Jan Barkmann", Corina Müller, Rainer \\ Marggraf
}

\author{
Correspondence: \\ Hendrik Hänke \\ Research Unit Environmental- and Resource Economics \\ Department of Agricultural Economics and Rural Development, \\ Georg-August-Universität Göttingen \\ Platz der Göttinger Sieben 5 \\ 37073 Göttingen \\ Germany \\ Email: hhaenke@gwdg.de
}

\begin{abstract}
The coastal area of the Mahafaly Plateau in southwestern Madagascar is prone to droughts, as well as to other environmental risks, resulting in frequent crop failures, famines, and extreme poverty. Thus, the identification of potential complementary livelihood sources has been identified as a crucial step for the sustainable development of the region. In this contribution, we assess the potential of prickly pear seed oil production as an income alternative for local communities. The prickly pears are cacti in the genus Opuntia Mill. and they are highly abundant in the region, particularly as living fences on farmland. From the seeds of its fruit, high-priced seed oil can be extracted. To investigate its economic potential, we inventoried prickly pears in field hedgerows through vegetation inventories and estimated the amount of seed oil that could be produced per household based on field sampling and laboratory analysis. To assess the socioeconomic impact of a potential large-scale project of regional Opuntia seed oil production, we conducted interviews with 51 farming households on human Opuntia consumption, the utilization of its cladodes as fodder, and other livelihood functions.

Five different prickly pears occur in the research region. We found that two out of these five species are highly important socioeconomically (Opuntia monacantha and O. streptacantha) and contribute $>50 \%$ to total food intake during periods of food shortage. Likewise, these species are consumed as a key water source and used as livestock fodder. In contrast, the other three Opuntia species are barely eaten by local residents or by livestock $(O$. dillenii, O. stricta and $O$. phaeacantha). These species are more spiny, and their fruits are virtually inedible due to a much higher seed content. The combination of low nutritional value and high seed content suggests promising seed oil production potential for these types of Opuntia. To avoid competition between human nutrition and the commercialization of local Opuntia seeds, sourcing strategies should exclusively target the fruit of the two high seed
\end{abstract}

species. However, investments for oil mills, skilled staff, and adequate logistics would be needed to create local value from this underrated resource in the Mahafaly region.

\section{RÉSUMÉ}

La zone côtière du plateau Mahafaly, dans le sud-ouest de Madagascar est caractérisée par un climat sec et aride, et est sujette à des risques environnementaux à l'origine de fréquentes récoltes de moindre qualité, de famines et d'une pauvreté extrême. L'identification de moyens complémentaires a été reconnue comme un étape clé pour le développement durable de la région. Le potentiel de la production d'huile obtenue à partir des graines de figues de Barbarie (Opuntia Mill.) a été évalué à titre d'alternative pour générer des revenus par les communautés locales. Les figues de Barbarie sont les fruits de cactus du genre Opuntia Mill. qui sont communs dans la région; les figuiers sont plus particulièrement utilisés pour servir de haies vives pour border les champs. Les graines des fruits contiennent de l'huile qui peut atteindre un prix élevé. Pour étudier le potentiel économique de cette huile, un inventaire des figuiers de Barbarie a été réalisé dans les haies vives bordant les champs, suivi d'une estimation de la quantité d'huile qui peut être extraite des graines par les ménages en procédant à des échantillonnages sur le terrain et à des analyses en laboratoire. Pour évaluer l'impact socio-économique d'un éventuel projet à grande échelle de production d'huile de graines de figues, 51 ménages ont été interrogés sur les différentes utilisations locales des figuiers de Barbarie.

Cinq espèces d'Opuntia ont été rencontrées sur la zone d'étude dont deux espèces ( $O$. monacantha et $O$. streptacantha) sont importantes d'un point de vue socio-économique. Lors des périodes de pénurie alimentaire, elles représentent plus de 50\% de l'apport alimentaire pour les gens de la région. Ces deux espèces sont aussi consommées comme une source d'eau clé et sont utilisées comme fourrage pour le bétail. Les trois autres es-

\footnotetext{
I Research Unit Environmental- and Resource Economics, Department of Agricultural Economics and Rural Development, Georg-August-Universität Göttingen, Platz der Göttinger Sieben 5, 37073 Göttingen, Germany

II Risk- and Sustainability Sciences, Hochschule Darmstadt - University of Applied Sciences, Haardtring 100, 64295 Darmstadt, Germany

Citation Hänke, H., Barkmann, J., Müller, C. and Marggraf, R. 2018. Potential of Opuntia seed oil for livelihood improvement in semi-arid Madagascar. Madagascar Conservation \& Development 13, 1: 34-44. http://dx.doi.org/10.4314/mcd.v13i1.4
} 


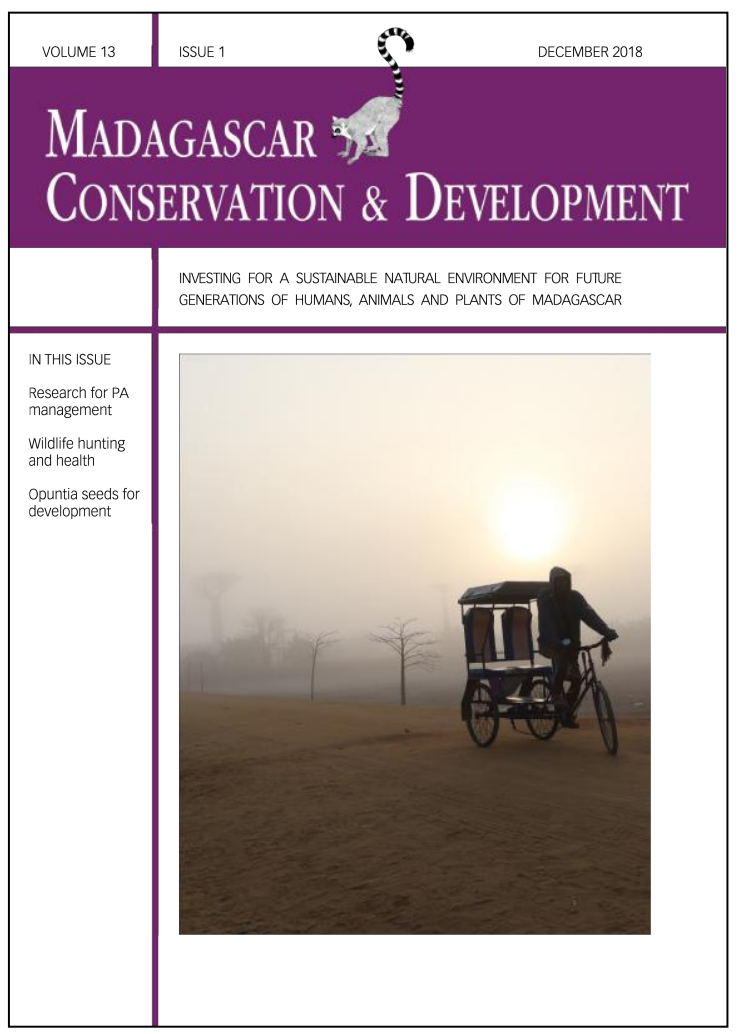

Madagascar Conservation \& Development is the journal of Indian Ocean e-Ink. It is produced under the responsibility of this institution. The views expressed in contributions to MCD are solely those of the authors and not those of the journal editors or the publisher.

All the Issues and articles are freely available at http://www.journalmcd.com

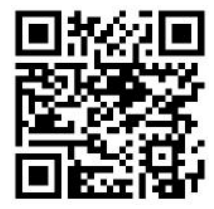

Contact Journal MCD

info@journalmcd.net for general inquiries regarding MCD funding@journalmcd.net to support the journal

Madagascar Conservation \& Development Institute and Museum of Anthropology

University of Zurich

Winterthurerstrasse 190

$\mathrm{CH}-8057$ Zurich

Switzerland

Indian Ocean e-Ink

Promoting African Publishing and Education

www.ioeink.com

Missouri Botanical Garden (MBG)

Madagascar Research and Conservation Program

Missouri Botanical Garden

BP 3391

Antananarivo, 101, Madagascar 
pèces d'Opuntia sont à peine consommées qu'il s'agisse des gens de la région ou du bétail ( $O$. dillenii, $O$. stricta et $O$. phaeacantha). Ces espèces sont plus épineuses et leurs fruits sont pratiquement immangeables en raison d'une teneur en graines beaucoup plus élevée. La combinaison d'une faible valeur nutritive et d'une forte teneur en graines suggèrent un potentiel prometteur pour la production d'huile de graines. Afin de ne pas mettre en péril les valeurs nutritives des figuiers pour les gens de la région avec la commercialisation des semences, les stratégies d'approvisionnement devraient cibler exclusivement les fruits des deux espèces qui présentent le plus de graines. Des investissements, comme ceux destinés aux huileries, un personnel qualifié et une logistique adéquate sont nécessaires pour créer une valeur locale à partir de cette ressource sous-estimée dans la région Mahafaly.

\section{INTRODUCTION}

There is an increasing global interest in prickly pear (Opuntia Mill.), particularly for the management of dry areas (Gebretsadik et al. 2013). Prickly pears are highly drought resistant due to their CAM physiology (Crassulacean Acid Metabolism, Sáenz et al. 2013), tolerate soil salinity well (Barbera et al. 1995, Ben Salem et al. 1996), are used to combat soil erosion (Nefzaoui and El Mourid 2007) and thrive in harsh environmental conditions in which other fruits and vegetables fail without irrigation (Han and Felker 1997). These beneficiary characteristics of prickly pear gave rise to an international Opuntia research and development program by the FAO (Food and Agriculture Organization of the United Nations): the FAO-ICARDA Cactus Network.

Opuntia seed oil is among the most valuable plant oils and it has become a highly attractive resource for the food, cosmetic, nutraceutical and pharmaceutical industries (Feugang et al. 2006, Moßhammer et al. 2006, Liu et al. 2009, Jana 2012, Sáenz et al. 2013, El Mostafa et al. 2014, Guillaume et al. 2015). The current prices for conventional produced Opuntia seed oil vary between 275 and $700 € /$, for organic oil between 900 and $1500 € /$ (In litt. with 6 international Opuntia seed oil trading companies (see Table S8)). It is mainly produced in Morocco, Algeria and Tunisia, commonly based on $\mathrm{O}$. ficus-indica. Due to its high share of polyunsaturated fatty acids (especially linoleic acid) and other components (tocopherols, sterols, phenolics), its seed oil is attractive for the cosmetic industry in Morocco (Sáenz 2017). However, the chemical components addressed in Opuntia seed oil are not exclusive to 0 . ficus-indica, but are also attributed to other species of Opuntia. spp. such as $O$. dillenii and O. stricta (antioxidants, polyunsaturated fatty acids, wrinkle-reduction effect; Stintzing and Carle 2005, Hamou 2007, Nazareno and Nefzaoui 2007, Yeddes et al. 2014), among others.

Originating from Mexico, prickly pears were introduced by colonial France to Madagascar and spread rapidly in the semi-arid south of the island (Kaufmann 2001, Middleton 2002). Prickly pears have existed in southern Madagascar for around 100 years and have naturalized (Kaufmann 2004). They are often described as invasive plants, particularly O. stricta (Lowe et al. 2000). Such invasive species could potentially threaten the autochthonous biodiversity of Madagascar (Kull et al. 2014). In the southern Malagasy Androy region, Larsson (2004) described O. stricta as an invader whereas some surveyed respondents stated that $O$. stricta is negatively impacting both livestock and human health (Larsson 2004).
However, there is no systematic description of prickly pear found in Madagascar. In addition, many prickly pears are often wrongly classified (Kiesling 1998, Binggeli 2003); crossbreedings, landrace strains and hybrids occur in Madagascar (Middleton 2009). Based on historical records and plant material stored in the Paris Museum of Natural History, Allorge and Matile-Ferrero (2011) have shown that the following prickly pears were introduced during the colonial period to Madagascar: O. cochenillifera, O. dillenii, $O$. ficus-indica and $O$. monacantha. After the eradication of O. monacantha due to an insect pest in the 1920s that was introduced and dispersed by the French colonisers (Middleton 1999), around ten other species of Opuntia were introduced to Madagascar in 1925 (Decary 1932).

Traditionally, prickly pears are an important plant for the livestock-based economy of the region: the cladodes of several Opuntia species provide dry season food and water for livestock after their thorns are burned; humans can consume the cactus pear fruit (Kaufmann 2004, Larsson 2004). In southern Madagascar, landholders traditionally plant prickly pears around villages, homesteads, cropping fields, and livestock corrals (Kaufmann 2001), occasionally also in fodder plantations (Götter 2016). The importance of prickly pears for Malagasy pastoralists is well documented. The plants increase the carrying capacity of the regional landscape by storing large amounts of water in their cladodes (up to $92 \%$ moisture content, Brulfert et al. 1984) and by generating substantial amounts of fodder biomass, complementing more strongly rain-dependent grassland biomass (Kaufmann and Tsirahamba 2006). Thus, some species of Opuntia are a key fodder and water source for animal husbandry in southern Madagascar (Middleton 2002, Kaufmann 2004, Larsson 2004). Some authors claim that the rise of pastoralism as a dominating regional livelihood strategy would not have been possible without the introduction of prickly pears used as cattle fodder (Middleton 1999, Kaufmann 2001). Likewise, there is evidence that prickly pear fruits provide an important food resource during the lean period for many farming households in semi-arid Madagascar. This role becomes particularly pronounced during droughts and ensuing food shortages (Kaufmann 2004, Andriamparany 2015, Noromiarilanto et al. 2016).

The human population in southwestern Madagascar is exceptionally poor. Local communities face an annual 'lean' or 'hunger' period (Malagasy: kere) from the beginning of the rainy season (November) to the annual crop harvest (April). During that period, a substantial share of the smallholder farming population runs low on subsistence food resources as well as cash, as many households have to reduce food intake to unhealthily low levels (Noromiarilanto et al. 2016, Hänke et al. 2017). With the next harvest not until weeks or even months ahead, non-farm income sources, livestock sales and the collection of wild plants are crucial to physically survive the lean season (Hänke and Barkmann 2017). One of the wild plants used intensively both by people and for livestock in Madagascar's southwest during the lean period are cactus pears (Opuntia spp.), also known in Malagasy as raketa. From the seeds of its fruit, one of the most valuable plant oils could be extracted offering an income alternative of substantial potential. Yet, little attention has been paid to the economic potential of Opuntia-derived products in Madagascar including the extraction of Opuntia seed oil.

Prickly pears have been assessed with regard to fodder quality (Nefzaoui and Ben Salem 2001, Gebretsadik et al. 2013), the chemical composition of their fruit (Tesoriere et al. 2004, Stintzing 
and Carle 2005, El Finti et al. 2013, Yeddes et al. 2014) and seed oi characteristics (Sawaya and Khan 1982, Ramadan and Mörsel 2003, Ennouri et al. 2005; Liu et al. 2009). In global reports, however, prickly pear seed oil content data show large variations ranging from $<4 \%$ to $>17 \%$ (Sawaya and Khan 1982, Coskuner and Tekin 2003, Ramadan and Mörsel 2003, Ennouri et al. 2006, El Mannoubi et al. 2009, Sáenz et al. 2013, Guillaume et al. 2015) making an extrapolation of local seed oil yields difficult. To our knowledge, analyses for fodder, fruits and seed oil of prickly pear found in Madagascar are not available to date. Likewise, little is known about (i) the quantitative abundance of prickly pear in southwestern Madagascar, and (ii) about the importance and exact uses of its different forms.

In this study, we focus on field hedges managed by farmers, where prickly pears often are planted as living fences (SuLaMa Marp 2011, Hanisch 2015). They are highly abundant, and their property rights are well defined, in contrast to e.g., communal land or wild growing prickly pears. Our research objectives are the following: (i) Identifying the different taxa of prickly pear and assess their quantitative abundance in the field hedges. (ii) Assessing the potential competition between traditional uses of prickly pear fruit, particularly during the lean season (contribution to food security, utilization as fodder, economic activities) and seed oil production. (iii) Assessing potential seed oil production per average farming household. This includes a prickly pear inventory, an estimate of fruit quantity per household, the determination of the seed content of the fruit, as well as of the oil content in its seeds. (iv) Determining the overall potential of commercialised prickly pear seeds as an alternative income source, requiring (a) a comparison of the seed oil content in a global context, and (b) consideration of accessible value chains and commercialisation options, including actual and potential uses of the by-products (e.g., fruit pulp, presscake) of prickly pear seed oil.

\section{METHODS}

Our study region covered the coastal plain of the Mahafaly Plateau in southwestern Madagascar (see Figure S1). The local population belongs to the Tanalana group. The area is semi-arid and received 200-300 $\mathrm{mm}$ rainfall during the years 2010-2015 (Centre National Antiacridien 2015), which is close to the limit of rain-fed arable agriculture (Kaufmann 2004). Moreover, droughts, dry spells and subsequent crop failures have become common in recent years (WFP 2015). The region belongs to the poorest and most disadvantaged areas in Madagascar (INSTAT 2011), which is itself among the ten poorest countries in the world (International Monetary Fund 2015, World Bank 2015). Water sources are scarce and the general infrastructure is weak (SuLaMa Marp 2011). Because of its high salinity, the groundwater is unsuitable for irrigation (Guyot 2002). The regional soils are sandy and of poor quality (low soil nutrients, low organic soil carbon; Andriamparany 2015, Hanisch 2015). Farmers grow cassava, sweet potatoes, maize, millet, sorghum and different leguminousous crops. Malnutrition is common in the area, with famines having occurred frequently in recent years (WFP and FAO 2014, WFP 2015, Noromiarilanto et al. 2016). With severely limited agricultural potential, off-farm income sources are crucial for a sustainable regional development. However, promising alternative income options are scarce in this remote and infrastructurally underdeveloped area of Madagascar (Hänke et al. 2017).
The region harbours unique, endemic biological diversity. The natural vegetation consists of highly specialised dry spiny forest with a plant and animal endemism rate of around 75\%-90\% (Fenn 2003, Jasper and Gardner 2015) and scattered samata trees (EUphorbia stenoclada). The level of endemism is among the highest in Madagascar (Fenn 2003, Gautier and Goodman 2003), which has, as such, one of the highest rates in the world (Myers et al. 2000). The research area is located directly west of the Tsimanampetsotse National Park (TNP).

OPUNTIA INVENTORY, SAMPLING AND OIL ESTIMATION. The

51 households were selected as a subset of a stratified random sample of a longitudinal, agroeconomic study conducted in 2014 (Hänke et al. 2017). Household clusters were developed based on Neudert et al. (2015) taking farm size, livestock possessing and wealth into account. We sampled the different household clusters proportionally to account for representativeness. Households were selected from three coastal villages in the sample: Efoetse, Maromatilike and Marofijery. They were selected because (i) they are all close to the national park and, therefore, receive special attention from conservation and development programs (e.g., Madagascar National Parks, World Wide Fund for Nature, and German Development Cooperation (GIZ), and (ii) some farmers had experience in selling prickly pear seeds.

The 51 households have a total of 87 fields whose hedges we inventoried. The prickly pear inventory, as well as complementing household surveys, were supported by three well-trained field assistants, and took place from February to May 2015. The prickly pear inventory consisted of five steps:

(a) Assessment of prickly pear cover in field hedges: To determine the prickly pear cover (in $\mathrm{m}^{2}$ ) within the fields' hedges, the length and width of the prickly pear hedges were measured in situ and the prickly pear species was noted. To do this, we randomly selected one third of the 51 households which resulted in a subsample of 17 households, including 29 single fields. To estimate the share of the different prickly pear in the hedges (\%), a rule of three was applied by using the spatial cover ( $\mathrm{m}^{2}$ per species) and the total hedge size $\left(\mathrm{m}^{2}\right)$. In addition, the total number of prickly pear plant stems was counted in the field hedges, so that we could compare our vegetation inventories with estimates done by interview respondents that were based on the number of stems.

(b) Number of fruit per household: A preliminary analysis of occurring prickly pear had indicated the presence of five taxa. One of them, a prickly pear locally called rengevoke (O. phaeacantha) was extremely rare and was therefore not considered in this study. Another form of prickly pear locally called vilovilo (O. streptacantha) was stated to be highly important as a food resource. Therefore, this form was also neglected from the succeeding analyses. In the study area, O. stricta var. stricta (Malagasy: mavozoloke and raketamena) is a low growing plant, usually $50-100 \mathrm{~cm}$ tall. O. dilenii (Malagasy: boritotse; synonym: 0 . stricta var. dilenii) is slightly taller: around 100-150 cm. O. monacantha (Malagasy: notsoke and viromena), however, grows far higher (up to $>3 \mathrm{~m}$ ). Due to the different growth forms, we applied two different methods for the fruit sampling.

After mapping the occurrence of the different prickly pears cacti, 30 distinct points were randomly placed in the 29 field hedges for each of the three most often occurring prickly pears. The random location of the sampling points was supported by QGIS. At the sampling points, $1 \mathrm{~m}^{2}$-squares were delineated, and 
the total number of $O$. dilenii and $O$. stricta fruit were counted. Finally, to estimate the number of fruit from these two prickly pears per household, the average number of $O$. dilenii and $O$. stricta fruit / $\mathrm{m}^{2}$ were multiplied by the spatial cover $\left(\mathrm{m}^{2}\right)$ of $O$. dilenii and O. stricta per household. Conversely, for 0 . monacantha, fruit sampling was done for individual plant stems instead of $\mathrm{m}^{2}$. To do so, the total number of fruit in 30 randomly chosen 0 . monacantha plant stems was counted. Finally, the total number of 0 . monacantha fruit per household was estimated through the number of $O$. monacantha plant stems in field hedges per household, multiplied by the number of fruit per plant stem. Since our in situ analyses covered fruit production during the lean season only, we asked locals how often the different prickly pear produce fruit during the year.

(c) Seed content and seed mass determination: In order to determine the seed content per prickly pear fruit (in mass percent) and dry seed mass (in $g_{d m}$ ) per prickly pear fruit, 30 pieces of fruit from $O$. dilenii, $O$. stricta and $O$. monacantha were randomly sampled, freshly weighted, their seeds were extracted, hand washed, and the seeds were freshly weighed. In order to determine the seed content (in mass percent), a rule of three was calculated using seed mass and total weight of the fruit. Subsequently, the seeds were oven dried at $68^{\circ} \mathrm{C}$ for 24 hours and weighed again in order to determine the dry seed mass $\left(g_{\mathrm{dm}}\right)$ per piece of fruit. Seed weight $\left(g_{\mathrm{dm}}\right)$ and seed content (in mass percent) of the three prickly pears were compared with t-tests.

(d) Oil content determination in prickly pear seeds: Preliminary analysis had already indicated an inverse relationship in the relative seed content of prickly pear fruit and human nutritional use. Consequently, it was clear early on that only the two rather inedible, high seed content species would qualify as targets for the commercialisation of prickly pear fruit and seeds. Thus, we chose to conduct a seed oil analysis for only these two varieties (O. dilenii and $O$. stricta) that were sourced directly in the study villages. Consequently, we ran a laboratory analysis in order to determine the oil content (in mass percent) in $O$. dilenii and O. stricta seeds. A petroleum ether analysis was conducted with an ANKOM XT 15 Extraction System. Through a fatty acid spectrum analysis, the level of linoleic acid was determined and a press-cake analysis for fibre, protein and fat content was conducted (analysis performed by SGS GmbH, Hamburg, Germany).

(e) Extrapolation of the average prickly pear seed oil production per household: To estimate the potential prickly pear seed oil production per average household, first the total number of fruits per household was calculated:

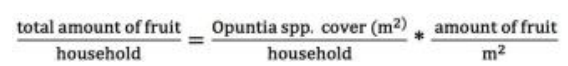

Then, the total seed oil $(\mathrm{kg}) /$ household was calculated by multiplying the total amount of fruit per household by the seed mass (dry mass) per fruit, as well as the seed oil content in mass percent:

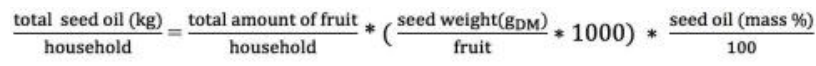

SURVEY. In addition to field inventories and laboratory analyses, we conducted interviews with the 51 farming households. Questions addressed included: Occurrence of prickly pear, fruiting periods and fruiting frequency per year, total number of prickly pear plant stems in their hedges. Prickly pear utilisation:
Which varieties are used for human consumption and which as livestock fodder? When are the different varieties eaten by humans? How many? How much do they contribute to overall food intake? What are the reasons for the (non-) consumption of the different prickly pears? Are there negative health impacts for both, humans and livestock? Economic activities involving prickly pear: Sale of fruit, sale of cladodes as fodder, renting out access to prickly pear stands for fodder. Experience with the sale of prickly pear seeds: How much labour is needed for the collection and separation of prickly pear seeds? What would be a fair price? What could be potential conflicts (e.g., competition) arising from the commercialisation of prickly pear seeds?

IDENTIFICATION OF OPUNTIA SPECIES. It is challenging to accurately identify the different species of prickly pear: there are around 190 species of which many have not been sufficiently described (Rebman and Pinkava 2001). To make things even more complicated, several landraces, their crossbreeds, as well as species hybrids occur all over the world. Therefore, we asked two opuntia specialists to support species identification based on pictures of the plants, flowers and spines that we provided.

Opuntia domestication began 9000 years ago and, since then, has often been divided wrongly into different species (Kiesling 1998). E.g., O. ficus-indica occurs in variable forms, mainly because of extensive selections for new types/varieties for more than 400 years (Helmuth Zimmermann pers. comm.). Indeed, $\mathrm{O}$. ficus-indica has been bred and introduced as a spineless form in many parts of the world, however, the plant has gradually converted back to the spiny form through gene recombination and selection (Helmuth Zimmermann pers. comm.). The locally called species vilovilo is a spiny Opuntia form, that also occurs in South Africa (Obermeyer 1976). It was previously wrongly classified as O. megacantha (Kiesling 1998). Lucas Majure (In litt.) identified this species more precisely as $O$. streptacantha belonging to $O$. ficusindica sensu lato.

\section{RESULTS}

OCCURRENCE OF OPUNTIA SPP. A total of five different pric-

kly pears were found in the field hedges investigated (see Table S2). One species (Opuntia phaeacantha) was extremely rare and was, therefore, omitted from the subsequent analysis. $O$. dilenii was said to produce fruit several times a year and all year long. However, it was not possible for local respondents to state exactly how often. Indeed, we encountered $O$. dilenii plants with no flowers, with flowers, mature, as well as with young fruit at the same time during our fieldwork.

IMPORTANCE OF OPUNTIA SPP. FOR HUMAN NUTRITION AND LIVESTOCK FODDER. Concerning nutrition, the respondents listed Opuntia monacantha and O. streptacantha, as most important for human consumption (Figure 1). According to respondents surveyed, this is due to the low seed content of its fruit. In contrast, $O$. dilenii and $O$. stricta have a high seed content. Our respondents reported that the fruit of these species tastes bad and that consumption results in digestive problems, particularly constipation. Also, O. streptacantha is less spiny, and thus its fruit is easier to harvest and consume.

Households collect $O$. monacantha and $O$. streptacantha mainly between October and April, that is, during the lean season. Around $78 \%$ of households collect mostly in March, and $12 \%$ 
mostly in April, which, according to local respondents, is the climax of the lean season where many households run out of food and cash (Hänke et al. 2017). During the lean season, local farmers consume $O$. monacantha and $O$. streptacantha fruit $(2.7 \pm 0.2$; mean $\pm 1 \mathrm{SE}$ ) roughly 2-3 times per day. Between 17 and 27 pieces of fruit are eaten per dish. Seventy-seven percent of the informants said that they eat dishes where $O$. monacantha and $O$. streptacantha are eaten exclusively $>10$ times per month, and that they contribute to $56.9 \% \pm 2.4 \%$ of their total nutrition during the lean period. Moreover, respondents specified that these fruits are also eaten as a water source, as water can become extremely scarce. More than 50 percent of the respondents stated that prickly pear fruit consumption would lead to health problems, with constipation cited most frequently. Likewise, infections caused by the spines during harvesting were mentioned.

As well as for nutrition, O. monacantha and 0 . streptacantha were ranked as the most important fodder resources of all prickly pear (Figure 1). To be used as fodder for cattle and goats, the cladodes are separated from the plants, and the thorns are burned off. According to survey respondents, the main constraints to their use as livestock fodder include diarrhoea in the animals, and physical wounds, which can lead to subsequent infections if the thorns are not sufficiently burned off.

ECONOMIC ACTIVITIES AND SALE OF OPUNTIA SPP. PROD-

UCTS. Forty-one percent of respondents confirmed that they regularly sell prickly pear products. However, on average, they consume far more themselves than they sell. The average proportion of own consumption to sale is $88.2 \% \pm 2.3 \%$ and $11.9 \%$ $\pm 2.3 \%$, respectively. Exclusively fruits from 0 . monacantha and O. streptacantha are sold.

During the dry season, when grasses and herbs are scarce, herders from the Mahafaly Plateau practice transhumance and migrate to the littoral (Feldt 2015). Here, they feed their livestock with the succulent twigs of the dry forest tree Euphorbia stenoclada and with prickly pear cladodes (Feldt 2015, Götter et al. 2015). Herders buy access rights to planted cacti areas, and some farmers in the littoral have even started to establish fodder plantations (predominantly Euphorbia stenoclada but also prickly pears; Götter 2016). Four percent of the households in our survey sell access rights to prickly pear areas to transhumant herders. The price varies between 135,000 and 187,500 ariary per hectare (42-58€). Also, small zebus and/or goats are occasionally exchanged for access to prickly pear cladodes. Fruit, however, was exclusively sold for human consumption for 13 to 38 ariary a piece (0.004-0.01€, see Table S10).

Experience with the sale of Opuntia seeds: Usually, prickly pear seeds are considered as waste by locals and thus discarded. From key informant interviews, we know that a local middleman bought small quantities of $O$. dilenii and $O$. stricta seeds between
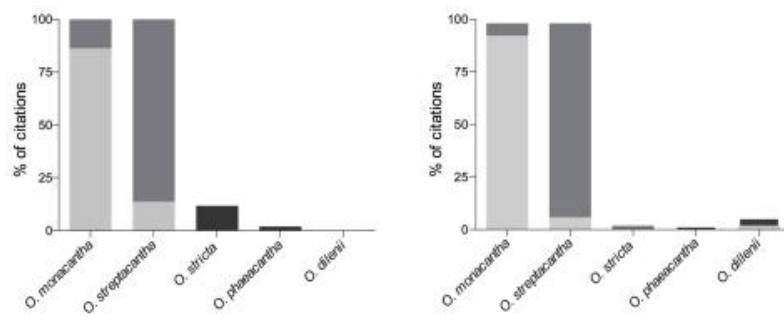

Figure 1. Ranking of Opuntia spp. for human nutrition (left) and livestock fodder (right). Light gray = most, to black = least important.
2010 and 2013. The seeds were shipped unprocessed, first to Antananarivo, and then to France.

Twenty-six per cent of the villagers surveyed had sold prickly pear seeds to middlemen in quantities of around $5 \mathrm{~kg}$ on average per year. In addition to the three villages covered in this study, several additional villages in the southern littoral delivered seeds. Villagers received a fixed price of 3000 Ariary $/ \mathrm{kg}$ for sun-dried seeds $(\sim 0.8 €)$. According to the villagers, a 'fair' price would be $3837 \pm 269$ Ariary $(1.16 € \pm 0.08 €$; mean \pm STE) per $\mathrm{kg}$ of sun-dried prickly pear seeds.

The villagers harvested the seeds in the following way: (i) the fruit were typically picked with spears, (ii) the fruit was separated from the thorns, (iii) the seeds were separated from the fruit, pulp and juiced by hand, (iv) and the seeds were hand-washed and (v) sun-dried. After being separated from the fruit, the pulp and juice were still consumable according to our respondents. Total labour for the collection and separation of prickly pear seeds was 3.3 \pm 1.4 hours per $\mathrm{kg}$ of sun-dried seeds.

PRICKLY PEAR IN FIELD HEDGES. The average farmer has 1.6

0.1 farm plots with an average plot size of $1.7 \pm 0.1$ ha (mean \pm STE). The farm hedges have an average size of $6015 \pm 451 \mathrm{~m}^{2}$ (0.6 ha) per field, from which $1012 \pm 126 \mathrm{~m}^{2}(16.8 \%$; Mean \pm 1 STE) consist of prickly pear on average (see SM6). Apart from prickly pears, farm hedges consist predominantly of Agave sisalana, Euphorbia stenoclada, Ziziphus spp. and several bushes. Prickly pear hedges consist, in sum, of $38.2 \%$ prickly pear with edible fruit (mainly Opuntia monacantha, some 0 . streptacantha), and of $61.8 \%$ prickly pear with inedible fruit (O. dilenii and 0 . stricta). On average, respondents estimated that a total of $2033 \pm 269$ prickly pear plant stems can be found in the hedges; according to our inventories it is $2268 \pm 608$ per household (Mean $\pm 1 \mathrm{STE}$ ) (Figure 2).

SEED MASS AND CONTENT IN OPUNTIA FRUITS. Dry seed mass per piece of fruit was significantly higher in Opuntia stricta than in 0 . dilenii and $O$. monacantha (t-tests, $p<0.001$, Figure 4). However, as the total mass per piece of fruit also differed for the different prickly pears, we also analysed the seed content (in mass percent) in fruit. Opuntia stricta had a significantly higher seed content than both $O$. dilenii and $O$. monacantha, while $O$. dilenii had a higher seed content then $O$. monacantha (paired t-tests, $p<0.001$, Figure 3).

FRUIT ESTIMATION AND POTENTIAL SEED OIL PRODUCTION.

The analysed $O$. dilenii seeds contained 7.04 mass percent of seed oil, and 0 . stricta, 8.80 mass percent. Households could potentially produce $1.97 \mathrm{~kg}$ of $O$. dilenii seed oil, and $12.03 \mathrm{~kg} /$ house-

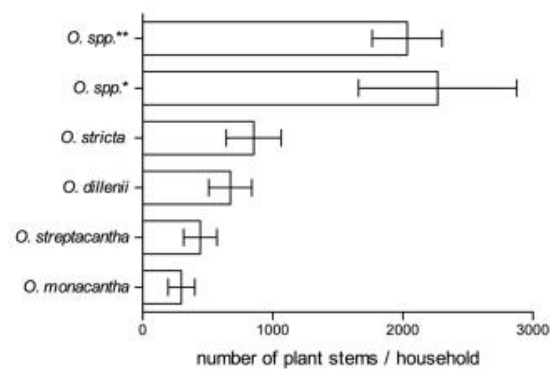

Figure 2. Number of plant stems per household from vegetation inventories compared to self-estimates from respondents, *is the sum of all Opuntia spp. below, ** is based on interviews, self-estimates are sums of all Opuntia spp. in households' hedges. Error bars indicate 1 standard error. 

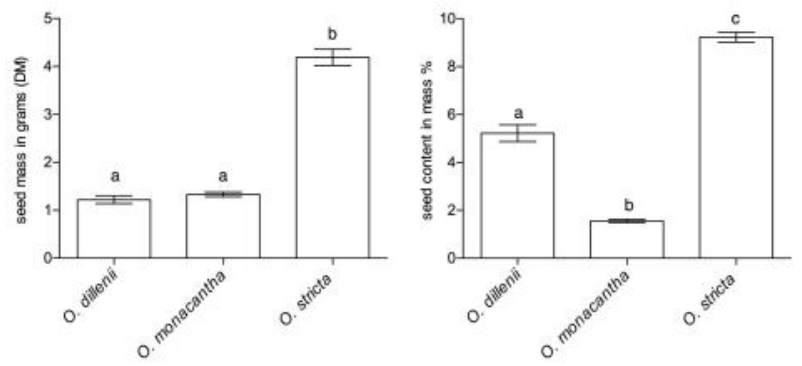

Figure 3. Seed mass and content of Opuntia spp. fruits. Error bars indicate 1 standard error; different letters indicate significant differences at $p=0.001$ in ttests (left) and paired t-tests in (right) respectively.

hold of $O$. stricta, on average, based on their resources in the field hedges (Table 1). The total number of pieces of fruit per household for 0 . monacantha was estimated based on the total number of plant stems per household (Table 2). However, its seed oil content was not analysed.

\section{DISCUSSION}

Decary (1925) claimed that semi-arid Madagascar would be uninhabitable without prickly pears. If lost, a crucial food, fodder and water resource would be absent, resulting in large-scale starvation. However, while Malagasy prickly pears are commonly treated as an undifferentiated group of species commonly referred to by their Malagasy name raketa (Allorge and Matile-Ferrero 2011), we find that the different prickly pears fulfil distinct functions for southwestern Malagasy land users. O. streptacantha and o. monacantha constitute a crucial natural resource for local livelihoods. Particularly during the lean season, these plants contribute a substantial share of total food intake, provide water,

Table 1. Average yieldable oil potential of Opuntia dilenii and Opuntia stricta per household (mean values and standard error), based on (a) surface $\left(\mathrm{m}^{2}\right)$ per household $(n=29)(b)$, an estimate of the number of fruit $/ \mathrm{m}^{2} /$ species in the lean season ( $n=30$ per species), (c) no of fruit per household per species $=$ combing (a) and (b), (d) mass (grams) per piece of fruit (fresh, $n=30$ per species), (e) seed mass(DM)/fruit, ( $f$ ) total seed mass(DM) / household= based on (c) and (e), (g) mass percent of oil in seeds, and (h) a final estimate of potential oil production per household based on (f) and (g).

Opuntia dillenii Standard Opuntia stricta Standard

\begin{tabular}{lllll} 
& \multicolumn{5}{c}{ Error } & var stricta & Error \\
\hline a. Surface $\left(\mathrm{m}^{2}\right) / \mathrm{HH}$ & 326.62 & 74.66 & 443.81 & 96.3 \\
b. No fruit/ m ${ }^{2}$ & 70.2 & 3.16 & 73.47 & 3.15 \\
c. No fruit $/ \mathrm{HH}$ & 22,929 & 235.56 & 32,607 & 303.39 \\
d. Mass per piece $(\mathrm{g})$ & 23.64 & 0.58 & 45.83 & 1.91 \\
e. Seed mass/ piece $\left(\mathrm{g}_{\mathrm{DM}}\right)$ & 1.22 & 0.08 & 4.19 & 0.17 \\
f. Total seed mass $\left(\mathrm{kg}_{\mathrm{DM}}\right) / \mathrm{HH}$ & 27.97 & 0.02 & 136.62 & 0.05 \\
g. seed oil mass \% & 7.04 & - & 8.8 & - \\
h. Seed oil $(\mathrm{kg}) / \mathrm{HH}$ & 1.97 & & 12.03 & \\
\hline
\end{tabular}

Table 2. Total seed mass per household of Opuntia monacantha, based on (a) surface $\mathrm{m}^{2}$ per household, (b) no plant stems per household, (c) number of fruits per plant, (d) number of fruit per household, (e) mass per piece (f) seed mass per fruit $g_{D M}$.

\begin{tabular}{lll} 
& $\begin{array}{c}\text { Opuntia } \\
\text { monacantha }\end{array}$ & $\begin{array}{c}\text { Standard } \\
\text { Error }\end{array}$ \\
\hline a. Surface $\left(\mathrm{m}^{2}\right) / \mathrm{HH}$ & 414.05 & 74.64 \\
b. No plant stems/HH & 297.8 & 102.09 \\
c. No fruit/ plant & 131 & 25.4 \\
d. No fruit $/ \mathrm{HH}$ & 39,012 & 1.896 \\
e. Mass per piece $(\mathrm{g})$ & 87.33 & 3.03 \\
f. Seed mass/ fruit $\left(\mathrm{g}_{\mathrm{DM}}\right)$ & 1.33 & 0.05 \\
g. Total seed mass $\left(\mathrm{kg}_{\mathrm{DM}}\right) / \mathrm{HH}$ & 51.89 & 87.73 \\
\hline
\end{tabular}

and-to a smaller degree-also function as an income source. Likewise, the cladodes of $O$. streptacantha and O. monacantha represent a key fodder source for livestock. Without prickly pear, pastoralism could probably not endure in this dry environment (cf. Middleton 1999, Kaufmann 2001). In contrast, O. dilenii and 0 . stricta are rarely eaten by humans due to their high seed content and an associated bad taste. Because of their heavy spines they are also less suitable as livestock fodder. Larsson (2004) reports similar findings from southern Madagascar (Androy region).

WHICH OPUNTIA SPP. ARE APPROPRIATE FOR OIL PRODUCTION? Even though the spatial cover of Opuntia monacantha is lower than that of $O$. dilenii and $O$. stricta, its total fruit production is comparable. This is due to its size of up to $3-4 \mathrm{~m}$ compared to the more stunted growth form of $O$. dilenii and $O$. stricta in southern Madagascar. Considering that $O$. monacantha has a significantly lower seed content at a higher total fruit weight, it is thus more suitable for human consumption, which was also corroborated by the interview respondents.

There could be potential conflicts with a commercialisation of the seeds of $O$. streptacantha and $O$. monacantha, given their high importance for livelihoods particularly during food scarcity. Their contribution to total food intake can reach $>50 \%$ during the lean period. This is in line with findings from the Androy region, where locals eat up to 50-70 pieces of fruit per person and day during the lean period (Larsson 2004).

While the high seed content species $O$. dilenii and $O$. stricta do not contribute to food security or livestock fodder, they made up $>60 \%$ of all prickly pears in the fields' hedges. Although it is conceivable that waste seeds from the consumption of $O$. streptacantha and $O$. monacantha could be used in seed oil production, a Malagasy oil processing company decided to source only 'red' prickly pear fruit (O. stricta and O. ficus-indica), and not 'green' fruit (species not specified), given their high local nutritional importance (Phileol 2013). Similarly, another Malagasy company is trading oil of O. dillenii (Renala 2017).

We found a higher seed oil content in $O$. stricta than in O. dilenii. With total seed oil contents of 7.0 (O. dilenii) and 8.8 (O. stricta; solvent extraction) mass percent, respectively, the values of Mahafaly prickly pear seed oil fall well within the reported ranges of oil yields, which varies between $<4 \%$ and $>17 \%$ (Sawaya and Khan 1982, Coskuner and Tekin 2003, Ramadan and Mörsel 2003, Ennouri et al. 2006, El Mannoubi et al. 2009, Sáenz et al. 2013, Guillaume et al. 2015). However, some of this variability may be due to differing maturation times of the fruit (Coskuner and Tekin 2003). Some of the published studies are based on fruits that are bought on European markets (Ramadan and Mörsel 2003), others are taken directly in the field, e.g., in North Africa (Ennouri et al. 2005, Yeddes et al. 2014). Also, most studies measured prickly pear seed oil content using solvent extractions, e.g., with hexane (Sawaya and Khan 1982, Ennouri et al. 2005, El Mannoubi et al. 2009, Ghazi et al. 2013). Yet, if the seed oil were generated through a cold press, seed oil yields would be lower due to higher losses using mechanical oil mills. Oil producers we contacted reported oil yields of around 4-5 mass percent from Malagasy 0 . stricta seeds in test pressings using mechanical mills.

The chemical components addressed in prickly pear seed oil marketing are not exclusive to the most-often studied $O$. ficus-indica, but are also attributed to other prickly pears. One of the components making prickly pear seed oil attractive for the cos- 
metical industry is its high share of polyunsaturated fatty acids (especially linoleic acid), tocopherols, sterols and phenolics (Sáenz 2017). The shares can vary according to production country and variety, but several studies found linoleic acid to be the dominating fatty acid in prickly pear seed oil, followed by oleic, palmitic and stearic acid. Comparing O. ficus-indica seed oils from Morocco, Turkey, South Africa, Tunisia, Chile and Algeria, Sáenz (2017) found shares of linoleic acid between $49.3-64.4 \%$, oleic acid between $15.7-23.5 \%$, palmitic acid between $10.6-13.7 \%$ and stearic acid between 3.2-5.4\%. Fatty acid shares for Tunesian 0 . stricta seed oil from Tunesia (Ennouri et al. 2005) and O. dillenii seed oil from Morocco (Ghazi et al. 2013) confirm that linoleic acid is the dominating fatty acid in Opuntia seed oil. In O. stricta seed oil from our study area, a linoleic acid share of $66.6 \%$ was found, followed by palmitic acid (12.5\%), oleic acid (7.9\%) and stearic acid $(4.5 \%$, which is well in the range of reported fatty acid spectrums.

OPUNTIA PRODUCTIVITY AND OPPORTUNITY COSTS. Our estimates on both plant and fruit numbers was generally in line with the ones of the respondents. If we sum up and transform our calculations of prickly pear fruit production per $\mathrm{m}^{2}$ to hectares (ha), they show average yields of around 25 tons/ha, which is in the medium range of global reported prickly pear fruit yields. Prickly pears have been shown to provide fruit yields of 13t/ha in Ethiopia (Gebretsadik et al. 2013), 30 t/ha in Italy (GAFÉIAS 2011) and up to 40t/ha in Argentina (Garcia de Cortázar and Nobel 1991).

The prickly pear fruit yield is remarkably high compared to the low agricultural yields in the region, e.g., cassava (0.7-1.0 t/ha; Milleville and Blanc-Pamard 2001, Noromiarilanto et al. 2016), which is the most important subsistence crop in the region. Accordingly, food self-sufficiency has been greatly negative in the past years for local farmers (WFP 2013, WFP and FAO 2014, Noromiarilanto et al. 2016, Hänke et al. 2017). Taking all income sources into account, local farming households earned around $15 €$ per month in 2015 , on average, whereas food sales contributed very little (Hänke et al. 2017). While the sale of livestock can often compensate for food gaps, its sale leads to a gradual depletion of household assets on the long-term (Hänke and Barkmann 2017).

The potential sale of more than $160 \mathrm{~kg}$ of seeds (Opuntia dilenii and $O$. stricta) per average household would generate $>540,000$ Ariary a year (155€) if we would apply the 'fair price'. However, total seed production is higher as the calculation is based on a single fruiting period. Both, $O$. dilenii and $O$. stricta give fruit several times a year and they do not only occur in the field hedges. As the fruit needs to be harvested, the seeds extracted, cleaned and dried, there is an opportunity cost in terms of labour spent on these activities. According to respondents' experiences, the complete Opuntia seed preparation for $1 \mathrm{~kg}$ took $3.3 \pm 1.4$ hours on average. Opportunity costs are low, however, with regard to (i) the low regional wages, e.g $0.5 €$ per day for fieldwork or construction work, (ii) the absence of income generating activities and (iii) the low income generated by agriculture in the region (cf. Hänke et al. 2017).

OPUNTIA STRICTA, AN UNAPPRECIATED INVASIVE SPECIES? Globally, Opuntia stricta is listed as one of the 100 most dangerous invasive species (Lowe et al. 2000) and studies from southern Madagascar have shown that $O$. stricta is far less appreciated by local communities then other prickly pears (Larsson 2004), which is in line with our findings. The study by Larsson (2004), however, has also shown that $O$. stricta is negatively impacting livestock and human health. Recent attempts to eradicate O. stricta plants e.g., in southern Madagascar (Androy region) have been unsuccessful (In litt. with Madagascar National Park Management and World Wide Fund for Nature). Nevertheless, the spiny growth form of $O$. stricta could be one of the reasons making it particularly suitable as living fences, as it protects fields from livestock and intruders. Indeed, 0 . stricta was introduced as living fence in many parts of the world (Foxcroft et al. 2008). Even though it is rarely consumed, it could, thus, still be beneficial for local land managers as a protection from field plots, particularly taking into account the high livestock numbers in the region (Feldt 2015, Hänke and Barkmann 2017).

While survey respondents appreciate $O$. stricta concerning food and fodder far less then 0 . streptacantha and 0 . monacantha, O. stricta was most common in the hedges, which may indicate an active management by local farmers. Agricultural fields are anthropogenic managed ecosystems, or social-ecological systems, where human preferences and values play an active role (Berkes and Folke 1998). Still, some respondents in our study regarded $O$. stricta as problematic, particularly since it can colonize agricultural fields. Yet, others stated that "If there is nothing else left, we also eat 0 . stricta". These contrasting views have also been confirmed from other parts of Madagascar, whereas particularly poor people were against eradication attempts of $O$. stricta by conservationists as it contributes to their food security, particularly in times of food scarcity (Middleton 2012). Similarly, research from South Africa has shown that although prickly pears are fought by governmental programs and/or conservationists for biodiversity conservation goals, they can contribute particularly to poor rural livelihoods, which has led to conflicts (Shackleton et al. 2011). Thus, due to opposing interests by different stakeholders, there is little chance of implementing biological control on invasive prickly pears in most countries (Zimmermann 2017).

A VALUE CHAIN APPROACH FOR OPUNTIA SEED OIL IN SOUTHWESTERN MADAGASCAR. From a rural development perspective on value addition, one would strive to process prickly pear seeds to the maximum degree possible in the research region itself. Potential income would be lost to the Mahafaly area if only raw, unprocessed seeds were exported. Occasionally, however, it is an economically superior option to export raw materials from countries such as Madagascar, as there are higher import duties associated with processed goods than for raw materials. Fortunately, this consideration does not apply to Madagascar as a least developed country (LCD). Due to the "EVerything-but-Arms" agreement between the European Union and several LCDS, import duties are charged neither on prickly pear seeds nor on its seed oil (European Commission 2015).

Most likely, quality considerations place the most challenging constraints on research area-based processing. To maintain the high concentration of antioxidants and unsaturated fatty acids, the oil mill needs to operate in a way that minimises contamination of the seed oil and its exposure to ambient air/oxygen. In turn, this requires an advanced level of technical equipment on the part of the oil mill, skilled staff, and adequate logistics. Historically, Morocco had extensive experience with the production of opuntia seed oil, and the needed requirements were probably easier to fulfil than in our research region. At the country level, 
however, a small number of enterprises are known to be capable of extracting quality prickly pear seed oil as they extract other fatty and/or essential oils from local plant sources, and commercialise them successfully globally, e.g., Phileol with Opuntia ficusindica and O. stricta (Phileol 2013), and Renala with O. dillenii (Renala 2017).

A further consideration applies to the type of oil production. Because of the hard seeds and their relatively low oil content, an extraction with solvents has considerable cost advantages. A solvent based extraction with, e.g., hexane, has the disadvantage, however, that this chemical solvent has to be removed from the seed oil after extraction, which becomes excessively expensive for higher grades of purification. Therefore, the quality of chemically extracted, commercial grade opuntia seed oil is regarded as inferior (Naturinstitut 2015). Even if extremely low solvent contents are technically feasible, the market favours seed oils extracted by traditional, i.e., physical/mechanical means. The mechanisms that result in a price premium for purely mechanically produced virgin olive and argan oil are in operation for Opuntia seed oil as well. Furthermore, the purity and natural qualities that consumers associate with Madagascar is at odds with chemical extraction from a marketing perspective, targeting the high value use of the seed oil, e.g., in natural cosmetics.

For oils traded in big quantities like for example palmoil, sunflower oil, rapeseed oil, soya bean oil, prices can easily be obtained through databases like FAOstat, Eurostat, UNComtrade, Index mundi, USDA National Agricultural Statistic Services, Statista.com, Destatis or AMIS Market Database. This is not the case for prickly pear seed oil. Six oil traders we contacted all pointed out that prices are not stable and depend on the purity and the quality of the oil. The current prices for conventional produced oil vary between $275-700 € / /$, for organic oil between $900-1.500 € / /$. Occasionally, prickly pear oil is mixed with cheaper oils and these mixtures are offered as prickly pear oil at a lower price (Oleador 2017).

With local seed oil content of 7.0-8.8\%, cactus pear seed processing with mechanical mills generates a substantial amount of presscake. The presscake of 0 . stricta has a low protein (7.2\%) and crude fat content (2.4\%), but a high fibre content $(50.5 \%)$ (analysis conducted by SGS Germany GmbH, Hamburg). Due to a fodder scarcity in the project region, especially during the lean period (Feldt 2015), prickly pear presscake could be used to feed ruminants, as they can digest high fibre fodder (Gebretsadik et al. 2013, Sáenz et al. 2013). Another by-product if prickly pear seeds are commercialised is the pulp and juice from its fruit. Juice and pulp could be consumed in the household, sold, or processed to yield jam (Sáenz et al. 2013). This also includes the less appreciated $O$. stricta varieties, since the seeds, reported to cause digestive problems, would be removed. For example, O. ficus-indica jams are successfully marketed globally, and can be easily produced through 'low-tech' techniques (Sáenz et al. 2013). The pulp of O. ficus-indica fruit contains glucose (35\%) and fructose (29\%), both in dry weight (El Kossori et al. 1998). Through the fermentation of its sugars, alcoholic beverages can also be produced (Sáenz et al. 2013), such as beer (e.g., Spottzl Brewery Co. and Borderland Brewing Co. for prickly pear beers).

GENDER AND INSTITUTIONAL ISSUES. According to local gender norms, the lower part of prickly pear plants is considered to be a male part, and the upper part a female part (Kaufmann
2004). The preparation of fodder from prickly pear cladodes is an activity conducted by males, while the collection and selling of fruit is a female activity (ibid). If this cultural division of labour were to continue, a commercialisation of prickly pear seeds may strengthen the economic position of women in local households. However, there are recent examples from other fodder plants in the research region that the rules for resource access are changing, i.e., from open access towards increasing privatisation (Götter and Neudert 2015). Three of the surveyed households sold access to prickly pear plantations as livestock fodder. With previously invariant cultural constants becoming more dynamic, the future distribution of benefits from the commercialisation of prickly pear fruit and seeds should be monitored carefully, as there is evidence that men and/or local elites tend to benefit predominantly from market integration in marginal rural communities (Genicot 2002, Basu 2007).

Because of the strongly differing seed content of the fruit, it appears unlikely that a problematically high share of edible prickly pear fruit will be removed from human subsistence consumption in favour of the commercialisation of prickly pear seeds. Although unlikely, it cannot be ruled out completely that local elite households would try to gain preferential access to (privately owned) field hedges and enforce a shift to planting more prickly pear with inedible seeds. However, with sufficiently high seed prices, field owners may find it in their own economic interests to switch to high seed content cactus pears, i.e., Opuntia stricta. The two high seed species were already most common in the field hedges. In the worst case, households not owning cactus pear hedges but previously having been granted some access to edible fruit may lose out. At this point, it is impossible to foresee whether the stronger overall economic base in the communities due to the commercialisation of cactus pear seeds could make up for this potential disadvantage.

\section{CONCLUSION}

The food security of rural households inhabiting the littoral of the Mahafaly Plateau is chronically low, complementing livelihood sources are lacking and extreme poverty is widespread. Two prickly pears with low seed content in their fruit (Opuntia streptacantha and $O$. monacantha) are crucial for human nutrition-and even water uptake_-during the annual lean season. Likewise, they represent a key fodder resource. On the contrary, $O$. dilenii and O. stricta have a high seed content, making them unsuitable for human nutrition. Their fruits neither contribute to the food security of local households nor are they dedicated as fodder sources for livestock. As the fruit of these two prickly pears grow most abundantly in the living fences of local fields, these two species represent a seed source for seed oil production. Furthermore, the cactus pear fruit yield is remarkably high compared to the low agricultural yields in the region. Our estimates of the average cactus pear seed oil yield per household demonstrate a substantial potential of the collection and pre-processing (cleaning, drying) of cactus pear seeds as an additional income source for local farmers. 0 . dilenii fruit is available throughout the year while 0 . stricta fruit can be harvested from March to August, coinciding with the period where households are harvesting annual crops as well as cassava (Hanisch 2015). Complementing current-often droughtsensitive-income sources, the sale of cactus pear seeds appears to be a potential additional, low-risk component of total household income. 
Local processing of the seed oil itself would further upgrade the local value chain, reduce transportation costs, and allow for local use of the press cake. However, financial capital is needed to acquire and operate oil mills, investments in training for local staff is needed, and adequate logistics are required. The more value addition would be done locally, the more livelihood improvements could be brought to some of the poorest rural communities in the world.

\section{ACKNOWLEDGMENTS}

We want to thank all participating households and our assistants, namely Jaonalison Henitsoa, Frank Hermé and Fenohaja Soavita. special thanks are due to Helmuth Zimmermann from the Africa Institute of South Africa, and Lucas Majure from the Desert Botanical Garden in Phoenix for support on species identification. We are also grateful to two anonymous reviewers and the editors who helped to greatly improve this paper. This research was possible due to a generous funding by the German research ministry (BMBF) through the Sustainable Land Management Program, specifically the SuLaMa project (Sustainable land management in southwestern Madagascar, see www.sulama.de).

\section{REFERENCES}

Allorge, L. \& Matile-Ferrero, D. 2011. Cactus et cochenilles introduits à Madagascar. mise au point à l'appui des collections historiques du MNHN à Paris. Revue Française d'Entomologie 33, 1-4: 55-64.

Andriamparany, J. N. 2015. Diversity, Local Uses and Availability of Medicinal Plants and Wild Yams in the Mahafaly Region of Southwestern Madagascar. Unpubl. Ph.D. thesis, University of Kassel, Witzenhausen. Avalable at <https://goo.gl/GrYqu5>

Basu, K. 2007. Coercion, contract and the limits of the market. Social Choice and Welfare 29, 1: 559-579. <https://doi.org/10.1007/s00355-007-0245-0>

Barbera, G., Inglese, P. and Pimienta-Barrios, E. 1995. Agro-ecology, Cultivation and Uses of Cactus Pear. FAO, Rome.

Ben Salem, H., Nefzaoui, A. Abdouli, H. and Ørskov, E. R.. 1996. Effect of increasing level of spineless cactus (Opuntia ficus indica var. inermis) on intake and digestion by sheep given straw-based diets. Animal Science 62, 2: 293-299. <https://doi.org/10.1017/S1357729800014600>

Berkes, F. and Folke C. 1998. Linking Sociological and Ecological Systems: Management Practices and Social Mechanisms for Building Resilience. Cambridge University Press, New York.

Binggeli, P. 2003. Opuntia spp., prickly pear, raiketa, rakaita, raketa. In: The Natural History of Madagascar. S. M. Goodman and J. P. Benstead (eds.), pp 335-339. The University of Chicago Press, Chicago, USA.

Brulfert, J., Guerrier, D. \& Queiroz, O. 1984. Rôle de la photopériode dans I'adaptation à la sécheresse: cas d'une plante à métabolisme crassulacéen, I'Opuntia ficus-indica Mill. Bulletin de la Société Botanique de France, Actualités Botaniques 131, 1: 69-77. <https://doi.org/10.1080/01811789.1984.10826634>

Centre National Antiacridien. 2015. Rainfall data for southern Madagascar 2010-2015. Tulear, Madagascar.

Coskuner, Y. and Tekin, A. 2003. Monitoring of seed composition of prickly pear (Opuntia ficus-indica L.) fruits during maturation. Journal of the Science of Food and Agriculture 83, 8: 846-849. <https://doi.org/10.1002/jsfa.1423>

Decary, R. 1925. L'utilisation des Opuntias en Androy (extrême sud de Madagascar). Revue de Botanique Appliquée et d'Agriculture Coloniale 50:769-771. <https://doi.org/10.3406/jatba.1925.4336>

Decary, R. 1932. Nouvelles cultures entreprises dans I'extrême Sud de Madagascar. Revue de Botanique Appliquée et d'Agriculture Tropicale 127: 195-197. <https://doi.org/10.3406/jatba.1932.5115>

El Finti, A., El Boullani, R. Fallah, M. and Msanda, F. 2013. Assessment of some agro-technological parameters of cactus pear fruit (Opuntia ficus-indica Mill.) in Morocco cultivars. Journal of Medicinal Plants Research 4, 35: 2574-2583. <https://doi.org/10.5897/JMPR12.1236>
El Kossori, R. L., Villaume, C., El Boustani, E., Sauvaire, Y. and Méjean, L. 1998. Composition of pulp, skin and seeds of prickly pears fruit (Opuntia ficus indica sp.). Plant Foods for Human Nutrition 52, 3: 263-270. <https://doi.org/10.1023/A:1008000232406>

El Mannoubi, I., Barrek, S., Skanji, T., Casabianca, H. and Zarrouk, H. 2009. Characterization of Opuntia indica seed oil from Tunisia. Chemistry of Natural Compounds 45: 521-524. <https://doi.org/10.1007/s10600-009-9448-1>

El Mostafa, K., El Kharrassi, Y., Badreddine, A., Andreoletti, P., Vamecq, J., et al. 2014. Nopal cactus (Opuntia ficus-indica) as a source of bioactive compounds for nutrition, health and disease. Molecules 19, 9: 14879-14901. <http://dx.doi.org/10.3390/molecules190914879>

Ennouri, M., Evelyne, B., Laurence, M. and Hamadi, A. 2005. Fatty acid composition and rheological behaviour of prickly pear seed oils. Food Chemistry 93, 3 : 431-437. <https://doi.org/10.1016/j.foodchem.2004.10.020>

Ennouri, M., Fetoui, H., Bourret, E., Zeghal, N. and Attia, H. 2006. Evaluation of some biological parameters of Opuntia ficus indica. Influence of a seed oil supplemented diet on rats. Bioresource Technology 97, 12: 1382-1386. <https://doi.org/10.1016/j.biortech.2005.07.010>

European Commission. 2015. The EU's Economic Partnership Agreements (EPAS) with Countries in Africa, the Caribbean and the Pacific (ACP). European Union, Brussels. Available at <http://trade.ec.europa.eu/doclib/docs/2013/april/tradoc_151010.pdf>

Feldt, T. 2015. Interrelatedness of Grazing Livestock with Vegetation Parameters and Farmers' Livelihoods in the Mahafaly Region, Southwestern Madagascar. Unpubl. Ph.D. thesis, University of Kassel, Witzenhausen. Available at $<$ https://g0o.gl/Mw96ZG>

Fenn, M. D. 2003. The spiny forest ecoregion. In: The Natural History of Madagascar. S. M. Goodman and J. P. Benstead (eds.), pp 1525-1530. The University of Chicago Press, Chicago, USA.

Feugang, J. M., Konarski, P., Zou, D., Stintzing, C. and Zou, C. 2006. Nutritional and medicinal use of Cactus pear (Opuntia spp.) cladodes and fruits. Frontiers in Bioscience 11: 2574-2589. <https://dx.doi.org/10.2741/1992>

Foxcroft, L. C., Richardson, D. M. and Wilson, J. R. U. 2008. Ornamental plants as invasive aliens: problems and solutions in Kruger National Park, South Africa. Environmental Management 41, 1: 32-51. $<$ https://doi.org/10.1007/s00267-007-9027-9>

GAFÉIAS (Global Association For Environmental Investments And Sustainability of economic, social and environmental spheres). 2011. The role of Prickly pea (Opuntia ficus-indica L.) in improving the livelihood of rural poor communities and restoration of degraded land in arid areas of Northern Ethiopia. GAFEIAS, Vienna. Available at <https://goo.gl/CnzbVT>

Garcia de Cortázar, V. and Nobel, P. S. 1991. Prediction and measurement of high annual productivity for Opuntia ficus-indica. Agricultural and Forest Meteorology 56, 3-4: 261-272. <https://doi.org/10.1016/0168-1923(91)90095-8>

Gautier, L. and Goodman, S. M. 2003. Introduction to the flora of Madagascar. In: The Natural History of Madagascar. S. M. Goodman and J. P. Benstead (eds.), pp 229-250. The University of Chicago Press, Chicago, USA

Gebretsadik, G., Animut, G. and Tegegne, F. 2013. Assessment of the potential of cactus pear (Opuntia ficus indica) as livestock feed in Northern Ethiopia. Livestock Research for Rural Development 25, 2: 1-10.

Genicot, G. 2002. Bonded labor and serfdom: A paradox of voluntary choice. Journal of Development Economics 67, 1: 101-127. <https://doi.org/10.1016/S0304-3878(01)00179-1>

Ghazi, Z., Ramdani, M., Fauconnier, M. L., El Mahi, B. and Cheikh, R. 2013. Fatty acids sterols and vitamin e composition of seed oil of Opuntia ficus indica and Opuntia dillenii from morocco. Journal of Materials and Environmental Science 4, 6: 967-972. Available at <http://hdl.handle.net/2268/156950>

Götter, J. F. 2016. The cattle raiders leave us no choice: New transhumance in the Mahafaly Plateau region in Madagascar. Madagascar Conservation \& Development 11, 1: 12-22. <http://dx.doi.org/10.4314/mcd.v11i1.3>

Götter, J., Antsonantenainarivony, O., Rabemirindra, H., Schlecht, E. and Watzold, F. 2015. Degradation of the Important Fodder Tree Euphorbia Stenoclada in Southwest Madagascar and Approaches for Improved Management. In: Tropentag 2015. Management of Land Use Systems for Enhanced Food Security: Conflicts, Controversies and Resolutions. 16-18 September 2015, Berlin. Available at <http://www.tropentag.de/2015/abstracts/links/Goetter_KoAhR9bd.pdf> 
Götter, J. and Neudert, R. 2015. From open access to a regime of mixed commonand private property: Indigenous appropriation and regulation of the fodder tree Euphorbia stenoclada in southwest Madagascar. In: Commons Amidst Complexity and Change, the Fifteenth Biennial Conference of the International Association for the Study of the Commons, pp 8. Edmonton, Alberta. Available at <https://goo.gl/ZNWABm>

Guillaume, D., Gharby, S, Harhar, H. and Baba, M. 2015. Opuntia ficus-indica and Balanites aegyptiaca oils: two seed oils to watch. Household and Personal Care Today 10, 2: 45-48.

Guyot, L. 2002. Reconnaissance hydrogéologique pour l'alimentation en eau d'une plaine littorale en milieu semi-aride: Sud Ouest de Madagascar. Unpubl. Ph.D. thesis. University of Nantes, Nantes. Available at <http://formad-environnement.org/GUYOT_2002.pdf>

Hamou, A. 2007. An overview on Medical and Cosmetic Uses of Cactus in Morocco. Cactusnet. Issue 11. International Center for Agricultural Research in the Dry Areas / Universidad Nacional de Santiago del Estero, Buenos Aires.

Han, H. and Felker, P. 1997. Field validation of water-use efficiency of the CAM plant Opuntia ellisiana in south Texas. Journal of Arid Environments 36, 1: 133-148. <https://doi.org/10.1006/jare.1996.0202>

Hanisch, S. 2015. Improving cropping systems of semi-arid south-western Madagascar under multiple ecological and socio-economic constraints. Unpubl. Ph.D. thesis. University of Kassel, Witzenhausen. Available at <https://goo.gl/q6zNFS>

Hänke, H. and Barkmann, J. 2017. Insurance function of livestock: farmer's coping capacity with crop failure in southwestern Madagascar. World Development 96: 264-275. <https://doi.org/10.1016/j.worlddev.2017.03.011>

Hänke, H., Barkmann, J., Coral, C., Enfors Kaustky, E. and Marggraf, R. 2017. Socialecological traps prevent rural development in southwestern Madagascar. Ecology And Society 22, 1: 42. <https://doi.org/10.5751/ES-09130-220142>

INSTAT. 2011. Enquête Périodique auprès des Ménages 2010. Institut National de la Statistique de Madagascar, Antananarivo. Available at <www.ilo.org/surveydata/index.php/catalog/1002/download/6357>

International Monetary Fund. 2015. World Economic Outlook Database. Washington D.C.

<https://www.imf.org/external/pubs/ft/weo/2013/01/weodata/index.aspx> accessed 24 May 2018

Jana, S. 2012. Nutraceutical and functional properties of cactus pear (Opuntia spp.) and its utilization for food applications. Journal of Engineering Research and Studies 3, 2: 60-66.

Jasper, L. and Gardner, C. 2015. Life Amongst the Thorns: Biodiversity Conservation of Madagascar's Spiny Forest. John Beaufoy Publishing, Oxford, UK.

Kaufmann, J. C. 2001. La question des raketa: Colonial struggles with Prickly Pear Cactus in southern Madagascar, 1900-1923. Ethnohistory 48, 1-2: 87-121. <https://doi.org/10.1215/00141801-48-1-2-87>

Kaufmann, J. C. 2004. Prickly pear cactus and pastoralism in southwest Madagascar. Ethnology 43, 4: 345-361. <https://doi.org/10.2307/3774032>

Kaufmann, J. C. and Tsirahamba, S. 2006. Forests and thorns: Conditions of change affecting Mahafale pastoralists in southwestern Madagascar. Conservation and Society 4, 2: 231-261.

Kiesling, R. 1998. Origen, domesticación y distribución de Opuntia ficus-indica. Journal of the Professional Association for Cactus Development 3: 50-59.

Kull, C. A., Tassin, J.and Carrière, S. M. 2014. Approaching invasive species in Madagascar. Madagascar Conservation \& Development 9, 2: 60-70. <http://dx.doi.org/10.4314/mcd.v9i2.2>

Larsson, P. 2004. Introduced Opuntia spp. in Southern Madagascar: Problems and Opportunities. Minor Field Studies No 285. University of Upsala, Upsala. <https://stud.epsilon.slu.se/12731/1/larsson_p_171019.pdf>

Liu, W., Fu, Y.-J., Zu, Y.-G., Tong, M.-H., Wu, N., et al. 2009. Supercritical carbon dioxide extraction of seed oil from Opuntia dillenii Haw. and its antioxidant activity. Food Chemistry 114, 1: 334-339. <https://doi.org/10.1016/j.foodchem.2008.09.049>

Lowe, S. J., Browne, M., Boudjelas, S. and De Poorter, M. 2000. 100 of the World's Worst Invasive Alien Species from the Global Inasvise Species Database. IUCN, Auckland, USA.
Middleton, K. 1999. Who killed "Malagasy Cactus"? Science, environment and colonialism in southern Madagascar (1924-1930). Journal of Southern African Studies 25, 2: 215-248. <https://doi.org/10.1080/030570799108678>

Middleton, K. 2002. Opportunities and risks: A cactus pear in Madagascar. Acta Horticulturae 581: 63-73. <https://doi.org/10.17660/ActaHortic.2002.581.3>

Middleton, K. 2009. From Ratsiraka to Ravalomanana. Changing narratives of Prickly Pears in dryland Madagascar. Études Océan Indien 42-43: 47-83.

Middleton, K. 2012. Renarrating a biological invasion: Historical memory, local communities and ecologists. Environment and History 18, 1:61-95.

Milleville, P. \& Blanc-Pamard, C. 2001. La culture pionnière du maïs sur abattis brûlis (hatsaky) dans le Sud-Ouest de Madagascar. 1. Conduite des systèmes de culture. In: Sociétés Paysannes, Transitions Agraires et Dynamiques Écologiques dans le Sud-ouest de Madagascar. C. Razanaka, S., Grouzis, M., Milleville, P., Moizo \& B. Aubry (eds.), pp 243-254. Actes de I'Atelier CNRE-IRD, Antananarivo. Available at <https://goo.gl/esL2zY>

Moßhammer, M. R., Stintzing, F. C. and Carle, R. 2006. Cactus pear fruits (Opuntia $s p p$.$) : A review of processing technologies and current uses. Journal of the$ Professional Association for Cactus Development 8: 1-25.

Myers, N., Mittermeier, R. A., Mittermeier, C. G., da Fonseca, G. A. B. and Kent, 2000. Biodiversity hotspots for conservation priorities. Nature 403,6772 : 853-858. <https://doi.org/10.1038/35002501>

Naturinstitut. 2015. Kaktusfeigenkernöl. $<$ <ttp://www.naturinstitut.info/kaktusfeigenkernoel.html> accessed 6 December 2015.

Nazareno, M. and Nefzaoui, A. 2007. Cactusnet. Issue 11. International Center for Agricultural Research in the Dry Areas/ North Africa Program Universidad Nacional de Santiago del Estero, Santiago.

Nefzaoui, A. and El Mourid, M. 2007. Cacti: A key-stone crop for the development of marginal lands and to combat desertification. Acta Horticulturae 811: 365-372. <https://doi.org/10.17660/ActaHortic.2009.811.50>

Nefzaoui, A. and Ben Salem, H. 2001. Opuntiae: a strategic fodder and efficient tool to combat desertification in the Wana region. In: Cactus (Opuntia species) as Forage. C. Mondragon and S. Perez (eds.), pp 73-90. FAO plant production and protection paper 169. FAO, Rome. <http://www.fao.org/3/a-y2808e.pdf>

Neudert, R., Goetter, J. F., Andriamparany, J. N. and Rakotoarisoa, M. 2015. Income diversification, wealth, education and well-being in rural south-western Madagascar: Results from the Mahafaly region. Development Southern Africa 32, 6: 758-784. <https://doi.org/10.1080/0376835X.2015.1063982>

Noromiarilanto, F., Brinkmann, K. Faramalala, M. and Buerkert, A. 2016. Assessment of food self-sufficiency in smallholder farming systems of southwestern Madagascar using survey and remote sensing data. Agricultural Systems 149: 139-149. <https://doi.org/10.1016/j.agsy.2016.09.005>

Obermeyer, A. A. 1976. Cactaceae. In: Flora of Southern Africa, the Republic of South Africa, Lesotho, Swaziland and South West Africa, Vol. 22. J. H. Ross (ed.), pp 144-156. Cape \& Transvaal Printers Ltd, Parrow, C.P., Government Printer, Pretoria, South Africa.

Oleador. 2017. Kaktusfeigenkernöl. Available at <https://goo.gl/CHtMYX> accessed 6 March 2017

Phileol. 2013. Valorisation des graines de figue de barbarie par Phileol Madagascar. Antananarivo, Madagascar. Available at <https://bit.ly/2s5tMls> accessed 5 March 2016

Ramadan, M. F. and Mörsel, J.-T. 2003. Oil cactus pear (Opuntia ficus-indica L.). Food Chemistry 82, 3: 339-345. <https://doi.org/10.1016/S0308-8146(02)00550-2>

Rebman, J. P. and Pinkava, D. J. 2001. Opuntia cacti of North America: An overview. The Florida Entomologist 84, 4: 474-483. <https://doi.org/10.2307/3496374>

Renala. 2017. Raketa Oil (Prickly Pear). <https://goo.gl/TQZz1a> accessed 5 October 2017.

Sáenz, C. 2017. Processing and utilization of fruit cladodes and seeds. In: Crop Ecology, Cultivation and Uses of Cactus Pear. pp 135-149. FAO, Rome. Available at <http://www.fao.org/3/a-i7012e.pdf>

Sáenz, C., Berger, H., Rodríguez-Félix, A., Galleti, L., Corrales García, J., et al. 2013. Agro-Industrial Utilization of Cactus Pear. Food and Agriculture Organization, Rome. Available at <http://www.fao.org/docrep/019/a0534e/a0534e.pdf> 
Sawaya, W. N. and Khan, P. 1982. Chemical characterization of prickly pear seed oil, Opuntia ficus-indica. Journal of Food Science 47: 2060-2061. <https://doi.org/10.1111/j.1365-2621.1982.tb12946.x>

Shackleton, S., Kirby, D. and Gambiza, J. 2011. Invasive plants-friends or foes? Contribution of prickly pear (Opuntia ficus-indica) to livelihoods in Makana Municipality, Eastern Cape, South Africa. Development Southern Africa 28 , 2: 177-193. <https://doi.org/10.1080/0376835X.2011.570065>

Stintzing, F. C. and Carle, R. 2005. Cactus stems (Opuntia spp.): A review on their chemistry, technology, and uses. Molecular Nutrition \& Food Research 49, 2 : 175-194. <https://doi.org/10.1002/mnfr.200400071>

SuLaMa Marp. 2011. Diagnostic participatif de la gestion des ressource naturelles sur le plateau Mahafaly. Tulear. Available at <http://www.sulama.de/files/rapport_marp_2011_mid.pdf >

Tesoriere, L., Butera, D., Pintaudi, A. N., Allegra, M. and Livrea, M. A. 2004. Supplementation with cactus pear (Opuntia ficus-indica) fruit decreases oxidative stress in healthy humans: a comparitive study with vitamin $\mathrm{C}$. The American Journal of Clinical Nutrition 80, 2: 391-395. <https://doi.org/10.1093/ajcn/80.2.391>

WFP (World Food Program). 2013. Global Food Security Update: Tracking Food Security Trends in Vulnerable Countries. Issue 12. October 2013. World Food Program, Washington D.C. <https://goo.gl/zJ1Wir>

WFP. 2015. Southern Africa Food \& Nutrition Security Working Group Report. World Food Program, Washington D.C.

WFP and FAO. 2014. FAO/WFP Crop and Food Security Assessment Mission to Madagascar, 23 October 2014. Food and Agriculture Organization of the United Nations. Rome. Available at <https://goo.gl/jZiyYR>

World Bank. 2015. Madagascar: Poverty Assessment. World Bank. Washington D.C. <https://goo.gl/oR9VHb> accessed 25 may 2018.

Yeddes, N., Chérif, J. K. and Trabelsi Ayadi, M.. 2014. Comparative study of antioxidant power, polyphenols, flavonoids and betacyanins of peel and pulp of three Tunisian Opuntia forms. Antioxidants 17, 5: 650-658. <https://doi.org/10.3923/pjbs.2014.650.658>

Zimmermann, H. 2017. Global invasions of cacti (Opuntia sp.): Control, management and conflicts of interest. In: Crop Ecology , Cultivation and Uses of Cactus Pears. P. Inglese, C Mondragon, A. Nefzaoui and C. Sáenz (eds.), pp 171-186. FAO, Rome.

\section{SUPPLEMENTARY MATERIAL}

Available online only

Figure S1. Study area.

Table S2. Occurring Opuntia spp., their fruiting rates/year, fruit color and fruiting periods

SM 3. Opuntia phaeacantha, O. streptacantha, O. dilenni, O. stricta var stricta, 0 . monacantha (left to right).

SM 4. Burning of spines of Opuntia spp. cladodes on plantations in the littoral; source: Tobias Feldt.

SM 5. Aerial view of a typical landscape in the coastal area illustrating living fences on farmland.

SM 6. Percentage of Opuntia spp. in field hedges.

SM 7. Fruits of $O$. streptacantha, 0 . stricta var stricta and $O$. dilenii (from left to right).

Table S8. Overview of Opuntia spp. seed oil prices over the past 10 years, mode of production and origin of oil.

Table S9. Shares of fatty acids in Opuntia spp. seed oils. Sources: 1: Sáenz 2017, 2a: Ennouri et al. 2005, 2b: own analysis, conducted by SGS Gmbh Hamburg, 3: Ghazi et al. 2013.

Table S10. Price variation of prickly pear products. 